stood Eleau disease. Various experiments in the preparation and disinfection of cane cuttings and in testing cane varieties for their resistance to disease that have been carried out are recorded, and should prove most helpful to growers.

The ninth and concluding section deals with free-living nematodes inhabiting the soil about the roots of cane and their relation to root diseases. The root diseases are very serious, and in these soil-inhabiting nematodes we have organisms capable, through their punctures, of giving entrance to smaller parasitic organisms that would hasten the death of the plant roots.

The author describes no less than eighteen new species of these worms, and records five more found around the roots of diseased canes in Hawaii. They are included in the genera Dorylaimus, Tylenchus, Mononchus, Prismatolaimus, Cephalobus, \&c., and one new genus, Anthonema, is described.

The whole work is excellent in every respect, not only from an economic point of view, but as an example of the thorough way in which such scientific investigations should be carried out.

The sixth report of the Woburn Experimental Fruit Farm deals with various washes used for the destruction of injurious insects. ${ }^{1}$ Among the more important experimented with were the alkali washes, paraffins and emulsions, lime-sulphur and others in connection with the destruction of the mussel scale (Mytilaspis pomorum). The portion of the report dealing with the paraffin oils and emulsions will prove of great value, and also from a scientific point of view much else in the report. But some of the results do not at all agree with what growers have found, such, for instance, that lead arsenate wash badly scorches the leaves under certain conditions and at certain strengths. It has not, it seems, been found to do so in their hands.

Some interesting work on silver leaf is given in conclusion. As a scientific chemical work it is all that could be desired, but the reader must take certain results with care, for if "egg-counts" have been made taking into account the following sentence, "we certainly found a greater destruction of eggs by insecticides in the case of scales which had been thus bored (by Chalcidid $\circledast$ ), than of those which were intact," then we must discount some of the results obtained. Some of the opening remarks might with advantage have been excluded by the authors.

But in spite of these few blemishes there is much useful reading, and horticulturists are indebted to the authors for their kindly interest, which we hope to see continued, for it is the first attempt at anything like sound treatment of the subject.

FRED. V. THEOBALD.

\section{THE POSITION AND PROSPECTS OF} CHEMICAL RESEARCH IN GREAT BRITAIN. ${ }^{2}$

The Status of Original Research.

TO ail who are familiar with the influence of scientific progress on the evolution of civilisation, that is, to all students of he hisfory of modern science, the general want of appreglation of research here cannot but be a matter of pr found It is not my intention to attempt andysis 1 he causes of this public apathy on the present foccalion. We must, I am afraid, deal with it as an accepted fact. Attention has from time to time been directed to this national weakness by the Press and by publicists whose influence should carry conviction to the lay mind. We can, no doubt, remember weighty utterances by statesmen such as the Duke of Devonshire, the late Lord Salisbury, Lord Rosebery, Mr. Chamberlain, Mr. Balfour, and, above all, in recent times, Mr. Haldane, who loses no opportunity of driving home the lesson of the importance of science and of scientific method to the national welfare. Nor have our scientific workers them1 "Sixth Report of the Woburn Experimental Fruit Farm." By the
Duke of Bedford, K.G., and Spencer U. Pickering, F.R.S. Pp. v+235. (Lnndon : Eyre and Spottiswoorte, rgo6.) Price $4 s$.

2 Abridged from the Presidential Address delivered at the annual general F.R.S.

No. 1966 , voL. 76$]$ selves failed to sound the note of alarm with all the authority of expert knowledge. But, in spite of these individual efforts, it cannot be said that we have made much headway; public interest in scientific research may still be considered to be on a low level-certainly lower here than in many other leading nations, and most decidedly lower than is desirable in the best interests of our country. A temporary flicker of excitement is caused when some sensational discovery is announced, or when some result of immediate practical (commercial) value is made known, but even in these cases the interest taken is only transitory and is narrowed down to the immediate issue; the broad cause which makes such results possible is lost sight of. The steady, plodding work which culminates in great discoveries is being carried on quite unheeded by the general public, and the workers themselves are practically unknown outside the ranks of science. Research as a "cult" is not understood; the national attitude towards the workers is one of "payment by results" in the very narrowest sense of the term.

How this state of affairs is to be remedied is a knotty question which I confess appears to me somewhat hopeless of solution at the present time. It may be that by persistent attack from within and the pressure of competition from without the country will, in fact must sooner or later, awaken to the situation. It may be that science will have to become more self-assertive and make its influence felt as a political power. There is need here, as has been often suggested, for a minister corresponding to the "Minister of Public Instruction," or the "CultusMinister" of other countries. The newly formed "British Science Guild" may fairly be expected in the course of time to help us in raising the level of public opinion towards the importance of research, this being, in fact, one of the primary objects for which this organisation has been founded.

\section{The Jubile of the Foundation of the Coal-tar Colour} Industry and its Lessons.

The exaltation of scientific research into an abstract principle or "cult," which is the keynote of the remarks which I have put together for your consideration on this last opportunity when I shall have the honour of addressing you from the presidential chair, is, of course, a familiar subject to all who keep in view the objects of a society such as this. If I venture to formulate the principle somewhat more emphatically on this occasion, it is that the international gathering, which took place here last summer in honour of our distinguished past-president, Sir William Perkin, and in celebration of the jubilee of the foundation of the coal-tar colour industry, has given rise to many considerations which are intimately associated with the subject of this address. Although at that memorable assembly the voice of the nations was raised in gratitude for and in recognition of the numerous benefits arising from the establishment of a great industry, we must not forget that below the chorus of praise and congratulation, so justly sounded in honour of the founder, there was flowing an undercurrent of thought which, in some of the addresses and speeches, found verbal expression-the thought that this industry owed its existence to scientific research, and that it had been developed into its present magnitude by the never-ceasing applications of research. Speaking generally, it may be said that all the great steps, the new departures in the industry of coal-tar products, have been the outcome of pioneering work carried on in the first place without immediate reference to practical results. All honour to those who have developed these results into manufacturing operations, but honour in the first place to the scientific pioneers! This is the real lesson taught by the celebrations of last July. It may be of interest to consider in the next place how far this lesson has been learnt here on the one hand by the scientific public and on the other by the general public.

That the lesson has not been learnt by those who are most immediately concerned, the manufacturers themselves, is sufficiently apparent when we compare the enormous development of the industry in Germany with its comparatively small development here and its decadence in France, once an active centre and a successful competitor with us in the manufacture of coal-tar colouring 
matters. With respect to the public attitude, it may be said that such appreciation of Perkin's work as was expressed through our Press was just what might have been anticipated in a country where the true position of scientific research is imperfectly understood. The rejoicing was over the purely practical achievement-the discovery of the convertibility by chemical processes of so many otherwise useless tar products into saleable articles of commerce. The public cannot, as matters now exist in this country, go behind such proximate results. Moreover, the limitation of the appreciation in this way brings out very clearly the difficulties which must be encountered in any attempt to raise the status of scientific research in general, and of chemical research in particular, in the national estimation. Consider, by way of contrast, the works of the littérateur or artist; these appeal directly to the public or to some section of the public, and can be appreciated according to their merits. Not so the labours of the scientific investigator; his achievements are measured solely by the, utilitarian standard; he is, as I said before, paid strictly by results. In other words, while literature and art have taken their position as "cults" in all civilised nations-a position to which they are fully entitled-science is judged by a lower and narrower standard, and certainly cannot be said to occupy in this country the same position as its sister branches of culture.

$\mathrm{My}$ contention is that scientific research, like every other branch of human culture, is worthy of national homage, whether it leads to immediately "practical" results or not - that its position in the scale of civilising agencies is not dependent upon such occasional stimulants as the jubilee of the foundation of a new industry or the announcement of a sensational discovery which furnishes materials for newspaper paragraphs. It would, I think, be generally admitted that any country which limited its appreciation of research to such branches of science as were likely to lead to industrial developments was on a low level in the scale of civilisation.

In maintaining the principle that scientific research has been, is being, and can always be carried on independently of its practical applications, I have no desire to give countenance to the view, somewhat prevalent, I fear, in this country, that there is some kind of antagonism between pure and applied science; that the scientifically trained chemist, for example, and the "practical " man, instead of being allies, as they should be, are in opposition. The days when such notions were held are, happily, passing away; if but slowly in this country much more rapidly abroad. My plea simply amounts to a claim for the re-adjustment of the positions of pure and applied science in the public estimation. The course of industrial development in the future is bound to become more and more interwoven with the development of pure science, and the perpetuation of erroneous ideas on this point cannot but act injuriously on both causes. In our own domain it is absurd to suppose that there is any antagonism between the two aspects of chemistry. Far from this being the case, it may safely be asserted from the experience furnished by the coal-tar industry that the rate of progress is actually measurable by the degree of substitution of pure science for empiricism. Those manufacturers who fail to recognise this principle do so at their own peril; those who have realised its truth cannot but admit that the more enlightened views respecting the function of science in the factory have been largely due to the influence of Perkin's work and example half a century ago.

\section{Chemical Research in Educational and Manufacturing} Centres.

I do not propose dealing in detail on this occasion with the very large question of the position of research in our universities, but putting the case broadly, we should, I think, all agree that after making allowance for the few noteworthy exceptions, the actual contributions to our science from these centres are far below the standard, both of quality and quantity, which might be expected and which we should all like to see attained. If any doubt on this point should exist. it is only necessary to call to mind the productive activity in the Continental universities as compared with our own. Judged by this standard, there can be only one conclusion-that many of our uni- versities are distinct failures as centres of chemical research, and that the total output of work from university laboratories is by no means worthy of the great traditions of this country as a pioneering nation in scientific discovery. If these seats of the highest learning, called into existence for the dissemination and promotion of knowledge, can give such a comparatively poor account of their achievements in chemistry, it is evident that there must be deterrent causes at work. It would be going beyond my province to attempt a detailed analysis of these causes here; they are numerous and not easy to deal with in a limited time, but some of them are of the same nature as those affecting the position of chemical research in other educational centres. They may be summed up under such headings as ancient traditions, defective educational methods, want of sufficient means leading to the frittering away of the research faculty by the drudgery of " coaching," the poor outlook for chemical research as a career, and the pedantic notion that a subject requiring for its advancement something akin to manual labour is derogatory to high scholarship. Behind these causes is the general public ignorance of and apathy towards research, to which I referred at the outset, and if I may paraphrase the utterances of recent authorities in the educational world, over them all is the trail of the examining board.

If we ask whether the modern educational development brought about by the technical education movement has fulfilled our expectations with respect to the advancement of chemical science, I for one must confess to a feeling of profound disappointment. There may be better times ahead when that era of public enlightenment dawns, but at present, with a few notable exceptions, these twentythree London polytechnics are, on the whole, so little productive that we may discount them as active centres of research. It must be remembered, moreover, that this class of institution has spread all over the country, and that the total expenditure in the way of money and teaching energy is so great in comparison with the output of original work that chemists have every right to ask why this state of affairs should exist.

Turning now to the consideration of the causes of this failure on the part of the new educational establishments, I must, in the first place, guard myself against the imputation that I am disparaging their work. The most acute form of disappointment is that which is experienced when we find weakness where we had looked for strength, and in emphasising their weakness from our standpoint I am not shutting my eyes to their usefulness in other directions. It is not a depreciation of the work which they are doing if we deplore their failure in another branch of work which they might be doing. From what I know of these institutions, and from information furnished by very good authorities, I am satisfied that in some directions, and more especially in connection with engineering and trade subjects and handicrafts-in all of which the artisan is an important element-they are doing a certain amount of good to the various industries concerned. But the danger for us is the general tendency in this country to ram the whole scheme of education into one mould, utterly regardless of the fact that the requirements of, let us say, an engineer are quite different from those of a chemist. It is for this, among other reasons, that our subject has suffered both in its scientific and industrial aspects, because the time and energy of the teachers of chemistry in these institutions are so largely frittered away in what might be called inconsequential labour on behalf of a class of student quite unprepared by previous training for assimilating the principles of our science and for the most part unable to give sufficient time to the subject to acquire any real working knowledge of it.

There is another factor to be added to those which are acting detrimentally towards the cause of research in these institutions, and that is the want of sufficient endowment. I am afraid that it is characteristic of our countrymen to neglect the most important interests until they are forcibly awakened to their danger, and then to try and make up for past neglect by rushing precipitately into the first plausible scheme that is presented. There is no doubt that the new educational development suffered much at the outset from this characteristic mode of procedure. The wrong kind of person was often allowed to frame the 
educational policy; the financial strength was exhausted in buildings and equipment, and the efficiency of the staff given only secondary consideration. We, of course, know that success in such educational work depends entirely upon the individual teacher-that the best mode of creating a school of chemistry, or any other subject, is to follow the advice of the late Sir William Flower with regard to the establishment of a museum : "First find a curator and let him build his museum around him." Had this principle been more generally adopted, the new institutions might by this time have been playing a really important part in the development of chenical science and chemical industry. As matters are, inadequate provision for maintenance having been made, the general standard of educational work is lowered in order that the grantearning requirements of some examining board may be met, and as a result the establishments have to be run as purely business concerns.

There are other minor evils acting as retarding influences with respect to our subject and arising from the same cause, namely, the necessity of conducting these newer institutions, more or less, as commercial establishments. The prevalence of the "business" spirit among the committees and governing bodies gives an exaggerated importance to what may be called the office staff-the registrars and clerks. The work of the office staff is capable of being appreciated by the average committeeman, while the work of the scientific staff is generally beyond his comprehension, except so far as it can be measured by financial gain to the institution. It is not sufficiently realised that men of business and administrative ability are by no means rarities, while really good teachers of science are much scarcer, and men who combine both the qualifications of a good teacher with the inspiring zeal of an original investigator are rarest of all. Now if, as was professedly the case, the modern departure in technical education had for its object the improvement of the industries, then it is sufficiently well known to us here that the future of our subject is with the men of the latter class, and the joint exertions of all the registrars and clerks, backed by the efforts of the most skilful chemical pedagogues who get through their syllabus within the session and earn the largest grants or score the highest percentage of successful "passes," will never raise the level of this country either in chemical science or chemical industry.

It is sometimes stated that it was never contemplated that research should be carried on in these institutionsthat this was the duty of the higher educational establishments. So it is the duty of the higher educational establishments, but the very fact that these are enabled to discharge their duty in a most imperfect way should have stimulated the newer institutions to make every effort to redeem our credit by making adequate provision for research. I will not venture to intrude my opinions concerning the vitalising influence of research upon other scientific subjects, but with regard to our own I have not the. least hesitation in declaring the belief that a school of chemistry which is not also a centre of research is bound to degenerate and to become a mere cramming establishment not worth the cost of the maintenance. It is easy enough to follow the actual course of the degeneration process in such an institution. The teacher, who may be a man of real ability and who has entered with the hope of finding time and opportunities for research finds himself, sooner or later, in the position of a chemical schoolmaster. The predominance of the business influence in the institution not only leads, as. I have already indicated, to the lowering of the level of the instruction and to his own consequent degeneration, but he is, as a further consequence, so overweighted with business and administrative work that these, superadded to his teaching duties, leave him neither time nor energy for original work. The spirit of research within him is strangled by officialism, and his teaching faculties deadened by the monotonous toil of the annually recurring drudgery of routine teaching.

The scale of remuneration also does not enable these institutions to command the services of the best teachers, although I do not think that this is the chief deterrent cause, as there are numbers of young chemists of firstrate training and ability who would be quite willing to devote their time at the outset of their career to acquiring teaching experience in these establishments, even at some personal sacrifice, if facilities for research were given. In the present state of affairs one can only marvel at the fact that so many men of ability can be found willing to take service in these newer institutions, the more especially as, apart from the absurdly inadequate remuneration often given to the chiefs of the chemical departments, the payment of the subordinate members of the staff is generally on a scale which is nothing short of a scandal to the wealthiest of European nations. Considering the long course of training necessary to produce a competent teacher or demonstrator, and in view of the actual amount of work expected from these men who, by virtue of their attainments and position, are compelled to live up to a standard of high respectability, it seems almost incredible that the average scale of remuneration should not exceed the wages earned by an artisan, and is often below that standard.

According to the "Official List of Appointments" published by the Institute of Chemistry last year, there are on the staffs of the London and suburban polytechnics about fifty-four trained chemists. To these may be added 237 engaged in teaching in similar institutions in provincial centres throughout the United Kingdom. In one respect the hopes of those who expected great opportunities for chemists from the new departure in technical education have been realised. At the present time there are in this country in round numbers some 290 posts available for teachers of chemistry, which posts have actually been created by the latest movement in technical education. If now we ask whether the output of original work from these 130 centres is representative of the productive power of the 290 teachers, there can, I think, be only one answer, and that an emphatic negative. An examination of the lists of teachers in these centres shows that only about twelve out of the total number are carrying on research, and most of these in a desultory way. It is evident that there is justification for my complaint that there is this submergence of creative faculty going on all over the country; the nets have been spread and the capacity has been caught, but so far with comparatively little effect upon the development of new schools of chemical research.

The consideration of the question of the position of factories as centres of research is intimately bound up with the educational side of the subject, because we have to deal now with the educational establishments which are supplying the chemists for our factories. The feeders of the chemical factories are the universities and technical schools, British and foreign, and the question before us as the custodians of research is whether the absorption of the chemical talent from these sources by the factories is justified from the industrial point of view-whether these products of modern training, having entered into such careers, are being used to the best advantage. In other words, is that wastage of original faculty which, as I have endeavoured to show, is going on in the educational institutions, going on also in the factories? Whether the total number of chemists employed in our factories is what it should be is a point for the manufacturers themselves to consider. Even the extreme estimate of $x_{500}$ does not seem a very large chemical staff for the whole of the factories of Great Britain. In the German colour industry alone, according to information supplied to us seven years ago as jurors for the Paris International Exhibition, five of the great factories were employing 557 chemists-real scientific chemists, and not mere testing machines such as are dignified with the name of chemist in many of our factories.

From my own experience as head of the chemical department of a technical college, and with some knowledge of the requirements of chemical industry, I can state that the newer technical education, when conducted in the form of organised courses of day instruction extending over several years, has enabled us to capture a large amount of chemical capacity. Of the total output of trained chemists from the various institutions, a fair proportiona number quite equal to the average in other countriesare possessed of the research faculty. We have seen what becomes of this when such men throw in their lot with the educational establishments. Are not we, the teachers, justified in asking whether the prospects of developing 
this faculty in our factories are such as might be reasonably expected from the known requirements of chemical industry?

In answer to this question I am afraid we must come to the conclusion that here also there is an enormous submergence of research talent going on. It is true that the position is improving - that some of our more enlightened manufacturers have realised the value of such men, and by taking advantage of their faculties have improved their various industries. But these cases are as yet exceptional, and the ideal will never be reached until the research laboratory becomes a recognised and well-staffed department in every chemical factory. Do our factories possess departments which can honestly be described as centres of research in the sense, say, of the research laboratories of the German colour factories? I am afraid not; indeed I know of scores of young men of great promise and ability who have been. swallowed up by the factories and gradually degraded, in the chemical sense, into mere machines carrying out routine work which really required no elaborate chemical education for its effective performance. There is, of course, no satisfactory means of measuring the influence of the newer education upon the chemical industries of this country, and we can only speak from individual experience concerning the careers of our own students. It is upon this experience that I base the conclusion that our country is wasting its resources in a most reckless way 80 far as concerns the chemical industries. There is an enormous amount of talent available if our manufacturers would only utilise it in the right way. It has frequently been pointed out how, on the Continent and in America, the educational establishments and the industries are brought into relationship by the cooperation between the manufacturers and the teachers. Here, so far as chemical industry is concerned, such cooperation is practically unknown, and, as a consequence, there exists more or less distrust where there should be confidence, and both the educational and the industrial sides of our subject are crippled. This is perhaps the most powerful influence at work in this country in checking that development which follows normally from cooperation between the representatives of science and of industry.

Checks to the Wastage of the Research Faculty; Research Funds and Scholarships.

Turning now from the consideration of the various deterrent influences, we may in the next place deal with such counteracting agencies as are available in this country. It is clear, from our point of view, that any means by wirich the research faculty, having once been captured, can be given free scope for development, must be a distinct gain to our cause. All who have had to do with the training of chemical students must in the course of their experience have come across young men of exceptional talent as original workers. We are concerned more particularly with the utilisation of this faculty for the promotion of our science and with the maintenance of the principle that the submergence of this faculty means so much dead loss to the national resources. Now it unfortunately happens that many of the men thus gifted come from stations in life which render it imperative that they should proceed at once from the college to some bread-winning occupation. A few may perhaps be lucky enough to find appointments in which there is scope for the development of their faculties, but I am afraid the majority do not; they undergo that process of extinction as original workers which I have already dealt with. One of the most valuable counteracting agencies, and one the importance of which, from our standpoint, cannot be overestimated, is that system of awarding research scholarships to men of proved ability so as to enable them to carry on original work after finishing their college training. The value of this most rational method of endowing research is due mainly to the fact that the right men are captured in the right way; they are not, as it were, squirted promiscuously out of an examination mould, but they are selected by the teachers who have had them under observation during the whole course of their training and who know their real as distinguished from their examinational capabilities.

The other agency working against the stream of adverse No. I 966 , VoI. 76$]$ influences is to be found in the various funds from which grants are made to individual workers for the prosecution of particular researches. There are three such funds available for the promotion of chemical research, the Government Grant Fund of the Royal Society, the grants distributed annually by the British Association, and the income derived from our own research fund. Of these, the two former have to be distributed over every branch of science, and chemistry takes its chance with other subjects. The total amount available for chemical research is not very large, and all who have served on the committees of any of these funds know very well that the amount applied for is generally much in excess of the sum available for distribution. The main difficulty of administration is, in fact, the equitable pruning of the various applications.

With regard to the results obtained through the research fund of this society, the present occasion is in every way opportune for directing attention to our achievements and to our needs. The income derived from this fund has hitherto enabled us to distribute annually a sum of about $220 l$.- a very modest amount considering the number of claims and the activity of our workers. Of the value of the assistance thus given we are, of course, all thoroughly aware here, but it may. not be generally realised by the outer public what an enormous amount of good work is being promoted by the judicious administration of this very modest income. In order to get at the actual facts, our assistant secretary, Mr. Carr, has been so good as to prepare a table covering the eight years from 1898 to 1905 inclusive, and setting forth for each. year the sum granted, the number of grantees, the total number of papers published by the grantees in our Journal or elsewhere, and other particulars which will be found in the table itself. From this it appears that 151 grantees during that period published 203 papers, thirteen failed to publish ten have not yet published, and eighteen grants are still in the hands of the grantees. The total amount granted was iz7ol., so that for this expenditure we have actually given to our science 203 papers, and more may be expected from those who still have grants in hand or who have not yet published their results. The figures as they stand, and even if nothing further is achieved, show that the grants average from $8 l$. to $g l$. per paper, and, as we all know, each paper represents the results of at least one and frequently of several years' work. It is not going too far to say that there are no funds giving such substantial returns for so small an expenditure as these research funds, and their importance as aids to the advancement of knowledge cannot be overestimated.

With the additional capital by which our fund has been increased, the total incone available for grants will be about 33ol. per annum. In view of the demands upon that income it is obvious that even now we are possessed of but very limited means, and that the research fund committee will still be compelled, as has hitherto been the practice, to allot the grants for the purchase of materials or special apparatus. But, in addition to the promotion of research by the means indicated, there is another, and, according to my view, an equally valuable method, for assisting our workers in the prosecution of their researches, and that is the allotment of personal grants to enable the grantees to secure skilled assistance -to purchase, in fact, the services of human material as well as chemicals and apparatus. It is only want of sufficient income that has hitherto debarred the use of our fund in this way. I am so confident that an extension of our means towards this end would be productive of a most notable increase, both in the quantity and quality of the chemical research done in this country, that I have no hesitation in placing upon record the opinion that the next step taken in the forward policy of the Chemical Society ought to be in this direction. To do much good in the way of making personal grants we should, of course, require to capitalise a very large sum; we want an income of thousands instead of hundreds, and I confess that I see no immediate prospect of realising this dream. But there can be no doubt that for those who have the interests of our science at heart there could be no better method of subsidising research.

The general conclusion which appears to be justified 
by this inquiry into the position and prospects of chemical research is, that the position here is by no means as satisfactory as we could wish-that much more might be done if the conditions were made more favourable for our active workers. In view of the actual achievements, accomplished in spite of the existing disabilities, it appears that the prospects for this country as a home of chemical research have been improving during the last decade with greater rapidity than at any previous period in the history of our society. But it is also obvious that there is much work yet ahead of us before the environment in which our workers find themselves is properly cleared from obstructions.

\section{UNIVERSITY AND EDUCATIONAL}

\section{INTELLIGENCE.}

OXFORD.-A large and brilliant company assembled in the Sheldonian Theatre/on Wednesday, June 26, to celebrate the Encæenia./The recently elected Chancellor, Lord Curzon/presided. Revery to a practice which has been disconfiued or ome years, the authorities reserved a portion of the apper gallery for unidergraduates. Honorary aeg were conferred upon a number of men of distinguished em/nence. The following is the text of the speeches delivered by Prof. Love in presenting the recipients of the degree of D.Sc. honoris causa. Dr. Ludwig Mond, F.R.S., upon whom the honorary degree of D.Sc. was to have been conferred, was unable to be present.

Sir Richard Douglas Powell, Bart., K.C.V.O.

Humani generis defensor contra phthisim, pestem omnium tæterrimam, inventus cst Ricardus Douglas Powell. Qui vir cum medicinæ se dedisset, ac præsertim huius morbi causas cognosceret, remedia excogitaret, curandi modos quos optimos esse iudicarat re probaret, summam gloriam et scientia et scriptis assecutus est. Difficile est pro meritis eum laudare qui nihil in vita egerit nisi ut laborantibus salutem afferat : illud brevissime dixerim hunc esse quo ne reges quidem nostri carere possint, seu adversa valetudine utantur, sive prospera. Fuit enim Reginæ Victoriæ nobis nuper ereptæ medicus ordinarius, et nunc Edwardo, regi nostro dilectissimo, medicus extra ordinem est. Viri merita declarat collegarum iudicium, a quibus Regalis Collegii Medicorum Præses factus est; declarant honores inusitati a rectoribus nostris collati, qui eum Baronettum et amplissimi ordinis Victoriani militem commendatorem creaverunt; declarant tacitæ tenuiorum gratiæ, quorum necessitatibus in maximis Londinii valetudinariis hic medicorum princeps ministrat.

Sir Norman Lockyer, K.C.B., F.R.S.

Inter eos qui solis stellarumque natura quæ sit optime docuerurt prinarium fere locum occupat Josephus Norman Lnrkyer. Dies me deficiat si miracula ab eo prolata de mundorum origine, de ratione quæ inter solis maculas et orbis terræ tempestatcs intercedat, si legationes solis defectus observandi causa in loca remotissima missas enumerare coner. $\mathrm{Ex}$ tot rebus gestis sumam duas tantum. Quadraginta abhinc annos duo viri, uterque suo Marte fretus, Jannssen in Gallia, in Britannia hic noster, instrumenta effinxerunt quibus usi flammas illas ingentes, quas e sole excurrere videmus quando eius orbi luna officit, sole non obscurato cernerent. Cum ex harum flammarum observatione multun de materia e qua sol constat colligi possit, res tanti habita est ab Academia Gallica ut numismate impresso insigniretur. Altera huius viri laus est singularis quod Acta Hebdomadalia, in quibus quicquid novi in omni Scientiæ Naturalis genere a viris doctis ubique repertum est enarratur, conscribenda curabit qua in re cum summam diligentiam et peritiam præstaret, de omnibus qui scientixe promovendæ student optime meritus est.

Sir William Ramsay, K.C.B., F.R.S.

In tenebris fere incognitis quæ inter Chemiæ et Physicæ fines irtercedunt nemo certius insistit quam Willelmus Ramsay. Testis est illa Baronis Rayleigh vox in hac urbe tredecim abhinc annos audita, qui, cum vaporem incognitum quendam in aere esse confirmaret, hunc virum inventi socium esse dixit. Rariora posthac metallorum NO. I 966 , vOL. 76 ] genera hic noster perscrutatus $c s t$, si qua huius vaporis vestigia deprehenderet; invenit autem non ipsum quidem vaporem sed metallum quoddam quod Helium vocant: hoc in sole exstare jam notum erat, nemo ulla eius apud nos indicia umquam odoratus est: mox cum de aeris natura subtilius quaereret, tres vapores novos detexit. His an is mirae eius metalli quod Radium appellatur virtutes it mutationes multorum animos commoverunt: hic vir exstitit qui stabile illud, quod ex his mutationibus gignitur, Helium esse ostenderet: quo facto causas quibus solis calcr atque lumen per sæcula innumerabilia alitur illustrare potuit.

\section{Sir Witllam Henry Perkin, F.R.S.}

$\mathrm{E}$ conchis radicibus, plantis, insectis antiqui pigmenta extrahebart, Willelmus Henricus Perkin inventus est qui ex carbonibus decoctis idem faceret, tanto successu ut hodie vel plantis vel animalibus supersederi fere possit. Quid? Nitidissimi calores quibus fulgent tot formosæ, quæ circumsedunt, dominæ, Doctorumque nostrorum vestes, quæ avium silvas Indicas incolentium plumas æmulantur, unde, quæso, hic splendor omnis profectus est nisi ex invento quod hic noster fecit, cum puer esset annos septendecim natus? Multi sunt, ut hunc omittam, qui ex hoc reperto divitias comparaverint, in Germania præsertim, ubi mercatores ita doctrina instituti sint ut inventa in usum convertere possint, et ea sit vectigalium ratio ut artificia nova pecuniis publicis adiuventur. Inventor ipse satis iam locupletatis se scientiæ totum dedit: lucis quidem repercussæ et ex alia re in aliam conversæ rationem et vim occultam nemo magis intellegit.

Prof. Witson Cheyne, C.B., F.R.S

Rationum Listerianarum, ut cum chirurgis loquar, quasi personam ferit Willelmus Watson Cheyne, qui et in his constituendis inventoris socius fucrit et in exercendis multo longlus progressus sit. Rebus in Africa Australi turbatis hic ad bellum profectus est civilis chirurgus cuius ope et cura milites uterentur. Dolendum est eius peritiæ tantum tum patuisse campum, medendi rationibus tantum fuisse opus : illud profecto gaudendum, hunc virum prasto fuisse qui sauciorum cruciatus leniret, quique chirurgiae ratione usuque omni instructus multorum vitam conservare posset : nullo quidem in bello antea gesto tot e vulneratis redire potuisse notum est. Hodie pace confirmata chirurgix rationes optimas exponit, dumque multitudinibus in magnas urbes congregatis succurrit, diligentiam peritiamque suam difficillimo belli tempore probatam vir strenuus præstat.

Manchester.-At the annual degree ceremony on June 29 the honorary degrees were conferred upon Baron D. Kikuchi and Prof. G. E. Hale, the presentation addresses being deliverg Sof. A. Schuster, F.R.S Baron Kachi Wrthily upholds the spirit of open-minded fraternjy why unites the universities of the world. A gradyan of Cambridge, he has occupied the chair of mathematrs in the Imperial University of Tokyo, and through his studies of the older mathematicians of Japan he has taught us interesting facts as to their methods of investigation. $\mathrm{He}$ has held the position of president of the Imperial University, and of Minister of Education; he has represented his country at important international conferences, and taken an active part in introducing a scientific system of weights and measures into Japan. Prof. G. E. Hale was formerly director of the famous observatory of the University of Chicago, built and equipped by the late Mr. Yerkes, and is the organiser and director of the Mount Wilson Solar Observatory, on the crest of the Sierra Nevada.

It is of interest to note that the M.Sc. degree was conferred upon the exceptionally large number of sixty-three candidates. Under the new regulations, the master's degree in sciepeds only obtainable upon satisfactory completion of post-graduate study or research, and there is thus every indication of the success of the scheme in increasing the spirit of research in the University.

Mr. J. Struthers, lecturer in agriculture and chemistry in the West of Scotland Agricultural College, Glasgow, has been appojzed secretary and agricultural chemist in Japan to the Asociación Salitrera, and leaves in August to take up is gew duties in Tokyo. 